\title{
SEASONAL VARIATIONS IN HEMATO-BIOCHEMICAL PARAMETERS IN MATURE ONE HUMPED SHE-CAMELS IN THE NORTH-WESTERN COAST OF EGYPT
}

\author{
M.T. Badawy ${ }^{1}$, H.S. Gawish ${ }^{1}$, Marwa. A. Khalifa ${ }^{1}$, F.D. El-Nouty ${ }^{2}$ and \\ G.A. Hassan ${ }^{2}$ \\ 1- Animal and Poultry Production Department, Desert Research Center, El-Mataria, \\ Cairo, Egypt, 2- Animal Production Department, Faculty of Agriculture, Alexandria \\ University, Egypt
}

\section{SUMMARY}

The study was conducted on four adult non-pregnant and non-lactating, onehumped she-camels, from March 2002 to February 2003 to cover the four seasons of the year. The study aimed to monitoring monthly and seasonally changes in hematological parameters and plasma biochemical constituents. Season of the year significantly affected $(P<0.01)$ all hematological parameters studied. Erythrocyte counts, packed cell volume, hemoglobin concentration and mean cell hemoglobin concentration were higher during the coolest and lower during the hottest seasons; an inverse trend was observed for mean cell volume. Significant seasonal changes in total leukocyte counts were observed, with values being higher in winter $(16.87 \mathrm{x}$ $\left.10^{3} / \mathrm{mm}^{3}\right)$ and lower in summer $\left(14.61 \times 10^{3} / \mathrm{mm}^{3}\right)$. Neutrophils were the major type of leukocytes in camels with highest percentage during summer (53.8\%) and lowest during winter (44.1\%). However, lymphocytes increased during the cooler seasons $(48.1 \%)$ and decreased in the hottest ones (40.1\%). Significant $(P<0.05)$ seasonal differences were observed for almost all plasma biochemical parameters studied. Plasma total proteins were higher in summer $(7.33 \mathrm{~g} / \mathrm{dl})$ than in winter $(6.59 \mathrm{~g} / \mathrm{dl})$. Albumin tended to increase during summer and autumn and decreased during spring and winter as well as globulin but with insignificant differences. Overall mean values of urea and creatinine were 30.97 and $0.9 \mathrm{mg} / \mathrm{dl}$, respectively with values being higher in summer and autumn, with similar trend for total lipids. Cholesterol values tended to increase from the lowest value in spring $(56.6 \mathrm{mg} / \mathrm{dl})$ to reach higher levels in both autumn $(75.3 \mathrm{mg} / \mathrm{dl})$ and winter $(65.6 \mathrm{mg} / \mathrm{dl})$ seasons. Glucose concentration and liver transaminases were also discussed. In conclusion, changes which might occur in hematological parameters during different seasons of the year might have an important role in adjusting the different functions of the animal's body with less physiological efforts within the so called neutral zone to the existing environmental conditions.

\section{Keywords: one humped camel, hematological and biochemical parameters}

\section{INTRODUCTION}

Changes in the environmental factors were found to exert pronounced effects on the blood characteristics to maintain the animal healthy and help animal to survive the adverse effects (Al-Arfaj et al., 1992). Camels (Camelus dromedaries)

Issued by The Egyptian Society of Animal Production 
physiology was different in many aspects when compared to other mammals, which help them to survive and flourish under drastic conditions of harsh environments and fluctuating nutritional conditions where other species can not exist. Hematological changes may have an important role in adjusting the different functions of the animal's body to existing environmental conditions especially under stressful ones (Nazifi et al., 1999 and Nyang-ao, et al., 1997). The aim of the present study was to investigate the adaptability of she-camel, Camelus dromedarius, to survive under semi-arid conditions in Egypt, by monitoring changes that might occur in some hematological parameters and plasma biochemical constituents in response to seasonal fluctuations in environmental conditions.

\section{MATERIALS AND METHODS}

\section{Animals and management}

The experiment was carried out at Maryout Research Station, Desert Research Center, Ministry of Agriculture and Department of Animal Production, Faculty of Agriculture, Alexandria University. Four healthy adult dry, non-pregnant and nonlactating, one humped she camels (Camelus dromedaries), 7-10 years old and $420 \pm$ $7.03 \mathrm{~kg}$ average body weight, were used to monitor monthly and seasonal changes in some hemato-biochemical parameters over full four seasons of the year from March 2002 to February 2003.

Animals were housed in an open yard and fed on a maintenance ration composed of a concentrate mixture $(50 \%$ corn, $47 \%$ barley, $2 \%$ minerals, $1 \%$ salt $)$ at the rate of $4 \mathrm{~kg} / \mathrm{head} /$ day, while Egyptian clover (Trifolium alexandrinum ) hay was offered ad libitium. Fresh water was available once daily, in mid-day. All animals were healthy and clinically free from diseases.

\section{Measurements}

Climatic data; ambient temperature (AT), relative humidity $(\mathrm{RH})$ and radiant ambient temperature (R.at), prevailing during the experimental period were recorded biweekly at 3 different times a day. The average values of the meteorological data are presented in Table (1).

Biweekly blood samples were taken from the jugular vein of the animal in the early morning before feeding and water offering. Blood withdrawn into heparinized tubes, then centrifuged at $3000 \mathrm{rpm}$ for $15 \mathrm{~min}$, to obtain plasma that was stored under $-20{ }^{\circ} \mathrm{C}$ for further analysis. Fresh blood was analyzed for hemoglobin concentration $(\mathrm{Hb})$, red blood cells (RBC's) count, packed cell volume (PCV), as well as leukocyte count and differential utilizing the conventional methods. Blood indices; mean corpuscular volume (MCV), mean corpuscular hemoglobin (MCH), mean corpuscular hemoglobin concentration (MCHC) were calculated using the formula proposed by Schalm et al. (1975). Plasma biochemical constituents including total protein (TP), albumin (AL), glucose (Glu), total lipids (TL), total cholesterol level as well as liver function (alanine aminotransferase (ALT) and aspartate aminotransferase (AST) and kidney function (urea and creatinine) were also determined using commercial kits produced by Biodiagnostics according to the manufacture procedures. Globulin concentration and $\mathrm{A} / \mathrm{G}$ ratio were also calculated. 
Table 1. Meteorological data prevailing at the experimental station during different seasons $(M \pm S E)$

\begin{tabular}{|c|c|c|c|c|c|c|}
\hline \multirow{2}{*}{ Time } & \multicolumn{4}{|c|}{ Seasons } & \multirow{2}{*}{ SE } & \multirow{2}{*}{$\begin{array}{c}\text { Overall } \\
\text { mean }\end{array}$} \\
\hline & Spring & Summer & Autumn & Winter & & \\
\hline \multicolumn{7}{|c|}{ Ambient Temperature $\left(\mathrm{AT},{ }^{\circ} \mathrm{C}\right)$} \\
\hline 08:00 hr & 20.7 & 25.5 & 19.0 & 10.2 & \pm 1.94 & 18.9 \\
\hline $14: 00 \mathrm{hr}$ & 26.4 & 39.3 & 28.3 & 14.3 & \pm 1.94 & 27.1 \\
\hline $20: 00 \mathrm{hr}$ & $19.3^{d}$ & 26.7 & 20.3 & 12.7 & \pm 1.94 & 19.8 \\
\hline Average & 22.1 & 30.5 & 22.5 & 12.4 & & \\
\hline \multicolumn{7}{|c|}{ Radiant ambient Temperature $\left(\mathrm{RAT},{ }^{\circ} \mathrm{C}\right)$} \\
\hline 08:00 hr & 22.0 & 26.3 & 21.7 & 16.3 & \pm 1.97 & 21.6 \\
\hline $14: 00 \mathrm{hr}$ & 31.8 & 42.0 & 32.3 & 22.8 & \pm 1.97 & 32.2 \\
\hline $20: 00 \mathrm{hr}$ & 20.0 & 24.0 & 20.0 & 16.3 & \pm 1.97 & 20.1 \\
\hline Average & 24.6 & 30.8 & 24.7 & 18.5 & & \\
\hline \multicolumn{7}{|c|}{ Relative Humidity (RH, \%) } \\
\hline 08:00 hr & 44.5 & 59.5 & 54.7 & 58.7 & \pm 2.71 & 54.4 \\
\hline $14: 00 \mathrm{hr}$ & 26.5 & 44.8 & 33.0 & 43.3 & \pm 2.71 & 36.9 \\
\hline 20:00hr & 52.3 & 63.7 & 61.7 & 57.7 & \pm 2.71 & 58.9 \\
\hline Average & 41.1 & 56.0 & 49.8 & 53.2 & & \\
\hline
\end{tabular}

\section{Statistical analysis:}

The analysis was conducted using SAS (1998) utilizing GLM procedure for repeated measurements. The differences between means were tested by Duncan's Multiple Range Test (DMRT). Data were statistically analyzed using the following model:

$\mathrm{Y}_{\text {eij }}=\mu+\mathrm{S}_{\mathrm{e}}+\mathrm{E}_{\mathrm{ij}} \quad$ Where ; $\mu$; the overall mean, $\mathrm{S}_{\mathrm{i}}$, is the effect of season (e, $1,2,3,4)$ and $\mathrm{E}_{\mathrm{ij}}$, is the random error.

\section{RESULTS AND DISCUSSION}

Results of the present study indicate that season of the year to have a significant $(\mathrm{P}<0.01)$ effect on almost all hematological parameters studied in she camels (Table $2)$. In the cooler months, RBC's count was higher during autumn $\left(12.6 \times 10^{6} / \mathrm{mm}^{3}\right)$ and winter $\left(11.8 \times 10^{6} / \mathrm{mm}^{3}\right)$ months and vice versa in the hottest months, being lower during spring and summer $\left(9.6 \times 10^{6} / \mathrm{mm}^{3}\right)$ seasons. Likewise, PCV, \% and $\mathrm{Hb}$ (g/dl) concentration followed the same trend reported for RBC's count. Results are in accordance with those reported in the literature (Ayoub et al. 2003 and Al Sultan, 2003). They attributed such changes to the hemodilution phase resulting from increasing water intake during summer season, where a considerable part is retained particularly in the extracellular compartment. The increase in total body water of animals during hot summer may supports this view (Taher, 1985).

The relative reduction in PCV values during summer season might be attributed to the reduction in circulating erythrocyte and increased rate of destruction in red blood cells (Shaffer et al., 1981). There was a significant negative correlation coefficient between PCV values and atmospheric temperatures. In contrary, Ghosal et al. (1973) in camels and Mehrovta and Gupta, (1989) in sheep, found that PCV was 
significantly increased during summer which was attributed to either the limited availability of oxygen to tissues that might stimulate hematopiosis resulting in increased PCV \% and better oxygen-carrying ability. The effect of heat stress which may cause a great mobilization of erythrocytes from spleen, lungs and liver is also a possible reason for increased PCV \% during hot seasons.

Regarding blood indices; lower MCV values were recorted during autumn (27.4 $\left.\mu^{3}\right)$ and winter $\left(29.5 \mu^{3}\right)$ seasons coinciding with higher RBC's counts (Table 2) and the opposite is true during spring and summer seasons. Values of $\mathrm{MCH}$ were higher (13.1 pg) during spring season than other seasons of the year $(<11.4 \mathrm{pg})$ while variations in $\mathrm{MCHC}$ were parallel to $\mathrm{Hb}$ concentration reflecting better oxygen carrying ability for camels under different climatic conditions.

Table 2. Changes in hematological parameters of one humped she-camels during different seasons of the year $(\mathrm{M} \pm \mathrm{SE})$

\begin{tabular}{lcccc|c}
\hline \multirow{2}{*}{ Parameters } & \multicolumn{4}{c|}{ Seasons } & \multirow{2}{*}{ SE } \\
\cline { 2 - 5 } & Spring & Summer & Autumn & Winter & \\
\hline Erythrocyte count $\left(10^{6} / \mathrm{mm}^{3}\right)$ & $9.6^{\mathrm{b}}$ & $9.6^{\mathrm{b}}$ & $12.6^{\mathrm{a}}$ & $11.8^{\mathrm{a}}$ & \pm 0.247 \\
Packed cell volume $(\%)$ & $33.1^{\mathrm{b}}$ & $31.6^{\mathrm{c}}$ & $34.4^{\mathrm{a}}$ & $34.9^{\mathrm{a}}$ & \pm 0.252 \\
Hemoglobin $(\mathrm{g} / \mathrm{dl})$ & $12.5^{\mathrm{a}}$ & $10.1^{\mathrm{b}}$ & $13.3^{\mathrm{a}}$ & $13.5^{\mathrm{a}}$ & \pm 0.238 \\
MCV $\left(\mu^{3}\right)$ & $34.6^{\mathrm{a}}$ & $33.2^{\mathrm{a}}$ & $27.4^{\mathrm{b}}$ & $29.5^{\mathrm{b}}$ & \pm 0.591 \\
MCH $(\mathrm{pg})$ & $13.1^{\mathrm{a}}$ & $10.7^{\mathrm{b}}$ & $10.7^{\mathrm{b}}$ & $11.4^{\mathrm{b}}$ & \pm 0.234 \\
MCHC $(\%)$ & $37.9^{\mathrm{a}}$ & $32.1^{\mathrm{b}}$ & $38.9^{\mathrm{a}}$ & $38.8^{\mathrm{a}}$ & \pm 0.593 \\
\hline Total leukocyte count $\left(10^{3} / \mathrm{mm}^{3}\right)$ & $16.97^{\mathrm{a}}$ & $14.61^{\mathrm{b}}$ & $15.44^{\mathrm{b}}$ & $16.87^{\mathrm{a}}$ & \pm 0.238 \\
Leukocyte differential distribution $(\%)$ & & & & \\
Neutrophil & $45.5^{\mathrm{c}}$ & $53.8^{\mathrm{a}}$ & $49.9^{\mathrm{b}}$ & $44.1^{\mathrm{c}}$ & \pm 0.723 \\
Eosinophil & $3.7^{\mathrm{b}}$ & $2.8^{\mathrm{c}}$ & $3.4^{\mathrm{b}}$ & $4.3^{\mathrm{a}}$ & \pm 0.115 \\
Monocyte & 2.0 & 2.3 & 2.8 & 2.8 & \pm 0.171 \\
Lymphocyte & $48.2^{\mathrm{a}}$ & $40.1^{\mathrm{c}}$ & $43.3^{\mathrm{b}}$ & $48.1^{\mathrm{a}}$ & \pm 0.657 \\
Basophil & 0.7 & 1.00 & 0.7 & 0.8 & \pm 0.090 \\
\hline MCV; Mean Corpuscular Volume, MCH= Mean Corpuscular Hemoglobin. & MCHC $=$ & Mean \\
Corpuscular Hemoglobin Concentration. & a-c Means with different superscript letters in the \\
same row differ significantly at $(\mathrm{P}<0.05)$ & & &
\end{tabular}

Results presented in Table 2 reveal significant seasonal changes in leukocyte counts; it was lower in summer and autumn than in winter and spring with values being $14.61,15.44,16.87$ and $16.97 \times 10^{3} / \mathrm{mm}^{3}$, respectively. The present results reveal that most physiological leukocytosis resulted from redistribution of existing cells and changes in blood volume due to altered water balance, because the increase in the total number of cells appear rapidly. Decreased leukocyte counts in summer compared with winter could be attributed to the reduction in corticosteroids secretion due to prolonged exposure to high environmental temperature during the summer season (El- Banna et al., 1981). Also, Al-Arfaj et al. (1992) reported that the elevated levels of neutrophils during summer in camels may be due to exposure to the dusty polluted warm environmental conditions. Neutrophils were the major type of leukocytes in camels with an overall mean of $48.3 \%$. The highest neutrophils percentage $(53.8 \%)$ was observed during summer, whereas the lowest percentage $(44.1 \%)$ was observed during winter season. These results agree with value of (43.8 
\%) in cattle as reported by Sharma et al. (1973). From another point of view, under heat stress, camel's nucleated erythrocytes do not synthesize heat shock protein (hsp73) after temperature elevation and camel's lymphocytes exhibited strong production of constitutively expressed heat shock protein (hsp73), providing thermotolerance to camel's blood cells, because lymphocytes have a higher resistance of general protein synthesis to elevated temperature (Guerriero and Raynes 1990 and Ulmasov et al., 1993).

Hematological parameters, plasma total protein and their fractions; albumin and globulin concentrations were higher $(\mathrm{P}<0.05)$ during the hottest months (summer and autumn) than the coolest months (spring and winter), with significant $(\mathrm{P}<0.05)$ differences for total protein and albumin while globulin concentration did not differ significantly (Table 3). These results are in harmony with those reported in dromedaries by Nazifi et al. (1999) and Kataria and Sharma (2002), in goats (ElNouty et al., 1988) and in sheep (More et al., 1980). The latter authors found that the increase in AT in summer was associated with a significant increase in total protein due to a significant increase in albumin and a slight increase in globulin resulting in non-significant alteration in A/G ratio. However, Saleh and El-Sokkary (2003) reported a reduction in albumin concentration during hot dry environment without any effect on mean total protein concentration in dromedary which contrasted with our results.

Results of kidney function tests indicated that season of the year exhibits a significant $(\mathrm{P}<0.01)$ effects on plasma urea and creatinine concentrations. Urea levels were higher during summer and autumn (34.99 and $30.29 \mathrm{mg} / \mathrm{dl})$ and lower during winter and spring (28.7 and $29.9 \mathrm{mg} / \mathrm{dl})$, respectively. These results confirm those reported by Nazify et al. (1999). The elevation of blood urea might be due to the combined pre-renal effects of reduced infusion with lower glomerular filtration and greatest load due to increased metabolic activity (Al Qarawi and Ali 2003). The overall mean values of urea and creatinine levels were 30.97 and $0.9 \mathrm{mg} / \mathrm{dl}$, respectively. These estimates are slightly different from those (32 and $1.9 \mathrm{mg} / \mathrm{dl})$ reported by Al-Sultan (2003), respectively. As in the other ruminant species, camels can utilize urea for microbial synthesis of protein and are able to regulate its excretion on the renal tubular level as well as sheep. Also, variations in urea clearance were found to be independent of either plasma urea concentration or the glomular filtration rate in she-camels (Al Qarawi and Ali 2003). Significant seasonal variations were observed in plasma glucose concentration (Table 3). Glucose concentration was highest $(119.2 \mathrm{mg} / \mathrm{dl})$ during winter and lowest during summer season $(74.1 \mathrm{mg} / \mathrm{dl})$. Generally, plasma glucose level in true ruminants is lower than in mono-gastric mammals. However, Dahlborn et al. (1992) reported that normally camels have a glucose level similar to mono-gastric mammals. Our estimates are higher than those previously reported by Al-Sultan (2003) on Mayhem breed of camels in Saudi Arabia $(58 \mathrm{mg} / \mathrm{dl})$. However, Nazifi et al. (1999) found that the concentration of serum glucose was significantly higher in summer than in winter. This discrepancy in the season effects on blood glucose in camels may be due to breed differences and to the environmental conditions particularly feeding and watering systems. The increased blood glucose level during summer may be due to decreased basal metabolic rate and reducing the use of glucose for energy production under hot climatic conditions. Present results showed that season of the year had a significant $(\mathrm{P}<0.01)$ effect on plasma total lipids and cholesterol concentrations 
(Table 3). Total lipids were higher (139 and $141 \mathrm{mg} / \mathrm{dl})$ during the hottest months (summer and autumn) than in either spring $(103 \mathrm{mg} / \mathrm{dl})$ or winter $(104 \mathrm{mg} / \mathrm{dl})$ with an overall mean of 121.8 and $65.9 \mathrm{mg} / \mathrm{dl}$, respectively. Cholesterol values tended to increase from the lowest one $(56.6 \mathrm{mg} / \mathrm{dl})$ in the spring season to reach higher levels in autumn $(75.3 \mathrm{mg} / \mathrm{dl})$ followed by winter $(65.6 \mathrm{mg} / \mathrm{dl})$ season.

Table 3. Changes in plasma biochemical parameters of she-camels during different seasons of the year $(\mathrm{M} \pm \mathrm{SE})$

\begin{tabular}{lccccc}
\hline \multirow{2}{*}{ Parameters } & \multicolumn{4}{c}{ Seasons } & \multirow{2}{*}{ SE } \\
\cline { 2 - 5 } & Spring & Summer & Autumn & Winter & \\
\hline Total Proteins (g/dl) & $6.52^{\mathrm{b}}$ & $7.33^{\mathrm{a}}$ & $7.25^{\mathrm{a}}$ & $6.59^{\mathrm{b}}$ & \pm 0.079 \\
Albumin (g/dl ) & $3.89^{\mathrm{b}}$ & $4.47^{\mathrm{a}}$ & $4.37^{\mathrm{a}}$ & $3.98^{\mathrm{b}}$ & \pm 0.048 \\
Globulin (g/dl ) & 2.61 & 2.87 & 2.88 & 2.62 & \pm 0.049 \\
Urea ( mg/dl ) & $29.90^{\mathrm{b}}$ & $34.99^{\mathrm{a}}$ & $30.29^{\mathrm{b}}$ & $28.71^{\mathrm{b}}$ & \pm 0.586 \\
Creatinine (mg/dl) & $0.80^{\mathrm{c}}$ & $0.89^{\mathrm{b}}$ & $1.04^{\mathrm{a}}$ & $0.87^{\mathrm{b}}$ & \pm 0.017 \\
Glucose (mg/dl ) & $101.4^{\mathrm{b}}$ & $74.1^{\mathrm{c}}$ & $80.4^{\mathrm{c}}$ & $119.2^{\mathrm{a}}$ & \pm 4.56 \\
Total lipids (mg/dl ) & $103^{\mathrm{b}}$ & $139^{\mathrm{a}}$ & $141^{\mathrm{a}}$ & $104^{\mathrm{b}}$ & \pm 3.20 \\
Cholesterol ( mg /dl ) & $56.59^{\mathrm{c}}$ & $62.85^{\mathrm{b}}$ & $75.25^{\mathrm{a}}$ & $65.63^{\mathrm{b}}$ & \pm 1.39 \\
ALT ( U / L ) & $15.21^{\mathrm{b}}$ & $17.47^{\mathrm{a}}$ & $16.69^{\mathrm{a}}$ & $13.91^{\mathrm{b}}$ & \pm 0.305 \\
AST ( U / L ) & $2.98^{\mathrm{b}}$ & $3.84^{\mathrm{a}}$ & $3.61^{\mathrm{a}}$ & $2.89^{\mathrm{b}}$ & \pm 0.084 \\
\hline
\end{tabular}

${ }^{\mathrm{a}-\mathrm{c}}$ Means with different superscript letters in the same row differ significantly at $(\mathrm{P}<0.05)$

The present results were in accordance with those of El-Masry et al. (1989) who reported that the increase in cholesterol and total lipids under hot months could be attributed to the increased non-esterified fatty acids and fat catabolism occurring in heat-stressed animals. However, Nazify et al. (1999) reported that TL and Cho concentrations were higher in winter than in summer in dromedary camels. It was suggested that the seasonal changes in blood lipids and proteins might result from changes in the nutritional and energy balances or changes in environmental temperature, humidity and day length. Additionally, the increased total lipids during summer might be attributed to the decreased usage of lipids as a source of energy in hot environment. The increase in cholesterol level observed during autumn agrees with those results of Shaffer et al. (1981) in dairy cattle.

Season of the year affected $(\mathrm{P}<0.01)$ activities of both ALT and AST enzymes in the plasma of camels. Estimated values were 17.5 vs. $13.9 \mathrm{u} / 1$ for ALT and 3.8 vs. 2.9 $\mathrm{u} / 1$ for AST in both summer and winter seasons, respectively (Table 3 ). These results are in agreement with those of Kataria and Bhatia (1991), Nazifi et al. (1999) and Al Qarawi and Ali (2003). The latter author reported that hyperthermia $\left(42{ }^{\circ} \mathrm{C}\right)$ caused significant increase in serum ALT and AST activities in adult bulls. However, Nyang-ao et al. (1997) found lower mean values of 6.2 and 2.7 U/L for both AST and ALT concentrations, respectively under hot and humid climates. Ben-Goumi et al. (1997) found that season and age did not affect enzymatic activities of ALT and AST, but noted variations especially in AST activity in dehydrated camels denoting that the reduction of plasma volume and consequently hemoconcentration causes an increase in serum AST, but ALT was not affected. Also, El-Anwar et al. (1993) found an increase in serum transaminases activities in camels during summer and 
suggested that this might be indicative for cellular impairment in the liver due to rapid gluconeogenesis in response to different stresses. On the other hand, Sarwar and Majeed (1997) suggested their possible involvement in liver function in particular globulin production. It was observed in the present study that activity of ALT is significantly affected by season of the year, while the globulin concentration was not affected, indicating that liver function was not extremely affected.

In conclusion, changes which might occur in hematological and biochemical parameters during different seasons of the year might have an important role in adjusting the different functions of the animal's body with less physiological efforts within the so called neutral zone to the existing environmental conditions.

Table 4. Correlation coefficients between meteorological parameters and some hemato-biochemical parameters in She-camels

\begin{tabular}{lccc}
\hline \multirow{2}{*}{ Parameters } & \multicolumn{3}{c}{ Meteorological Parameters } \\
\cline { 2 - 4 } Erythrocyte count & AT & RAT & RH \\
Packed cell volume & $-0.52^{*}$ & $-0.54^{*}$ & 0.17 \\
Hemoglobin concentration & $-0.83^{*}$ & $-0.84^{* *}$ & -0.12 \\
Leucocyte count & $-0.78^{*}$ & $-0.81^{* *}$ & -0.36 \\
Neutrophils & $-0.59^{*}$ & $-0.60^{*}$ & -0.47 \\
Lymphocyte & $0.83^{* *}$ & $0.84^{* *}$ & 0.47 \\
Total protein & $-0.76^{* *}$ & $-0.77^{* *}$ & $-0.58^{*}$ \\
Albumin & $0.60^{*}$ & $0.60^{*}$ & $0.52^{*}$ \\
Urea & $0.63^{* *}$ & $0.63^{* *}$ & $0.56^{*}$ \\
Creatinine & $0.68^{* *}$ & $0.70^{* *}$ & 0.37 \\
Total lipids & 0.13 & 0.10 & 0.27 \\
Glucose & $0.69^{* *}$ & $0.68^{* *}$ & 0.47 \\
Alanine aminotransferase & $-0.86^{* *}$ & $-0.85^{* *}$ & -0.24 \\
Aspartate aminotransferase & $0.68^{* *}$ & $0.68^{* *}$ & 0.41 \\
\hline AT. Ami*n & 0.71 & $0.70^{* *}$ & 0.23 \\
\hline
\end{tabular}

AT. Ambient temperature. RAT. Radiant ambient temperature. $\mathrm{RH}$, relative humidity.

$*, \mathrm{P}<0.05 \quad * *, \mathrm{P}<0.01$

\section{REFERENCES}

Al-Arfaj, N.M., K.A. Attia and S.Y. Saleh, 1992. Some physiological studies on the blood cellular elements of camel with reference to certain immunological properties of lymphocytes. Vet. Med. J. Giza, 40: 115 - 120.

Al-Sultan, S.I., 2003. Studies of some normal biochemical parameters of Majaheem breed of camel (Camelus dromedarius) in Saudi Arabia. J. Anim Vet. Advances, 2: $646-647$.

Al Qarawi, A.A.; B.H. Ali, 2003. Variations in the normal activity of esterases in plasma and liver of camels (Camelus dromedarius), cattle (Bos indicus), sheep (Ovis aries) and goats (Capra hircus). Journal of Veterinary Medicine Series A., 50 (4): 201-203.

Ayoub, M.A.; A.A. El Khouly, T.M. Mohamed., 2003. Some haematological and biochemical parameters and steroid hormone levels in the one-humped camel 
during different physiological conditions. Emirates Journal of Agricultural Sciences., 15 (1): 44-55.

Ben-Goumi, M., B. Faye, K. El-kami and F. Farge, 1997. Clinical enzymolology in dromedary camel ( Camelus dromedarius) part 2- Effect of season, age, sex, castration, lactation and pregnant in serum AST, ALT, GGT, AP and LDH activities. J. Camel Pract. Res. 4: $25-28$.

Dahlborn, K., S. Benlamlih, R. Zine-Filali., E. Gueroulali, J. H. Hilali, and M. Oukessou., 1992. Food deprivation and refeeding in the camel (Camelus dromedarius). Amer. J. physiol. 262: 1000 - 1005.

El-Anwar, A.H., E.A. Mabrouk and S.S Ibrahim., 1993. Effect of muscular exercise on some serum biochemical constituents in camels. Vet. Med. J. Giza. 41: $83-$ 85.

El-Banna,I.M, F.D. El-Nouty, and H.D. Johnson., 1981. Plasma glucocorticoid levels in dehydrated camels under hot environment. Alexandria J. Agric. Res. 29: 531 543.

El-Nouty, F.D., G.A. Hassan, T.H., Taher, .A. Samak, M. Z .Abo-Elezz and M.H. Salem., 1988. Water requirements and metabolism in Egyptian Barki and Rahmani sheep and Baladi goats during spring, summer and winter seasons. J. Agric. Sci. 111: 27 - 34

El-Masry, K.A., A.I. Aboulnaga, and I.F. Marai., 1989. Concentrations of cortisol, proteins and lipids in goats as affected by season, sex and location. Third Egyptian-British conference on animal, Fish and poultry production. Alexandria, 7-10 Oct. 469-475.

Ghosal, A.K., T.C. Appanna and P.K. Dwaraknath., 1973. Studies on the seasonal variations in the blood constituents of Indian camel (Camelus dromedarius). Ind. J. Anim. Sci 43: $642-644$.

Guerriero, V. and A.D. Raynes., 1990. Synthesis of heat stress protein in lymphocyte from livestock. J. Anim. Sci. 68: 2779 - 2783.

Kataria, N. and J.S. Bhatia., 1991. Activity of some enzymes in the serum of dromedary camels. Res. Vet. Sci. 51: $174-176$.

Kataria, A.K. and K.M. Sharma., 2002. Serum protein and Immunoglobulin profile in camels (Camelus dromedarius). Ind. J. Anim. Health 41: 5 - 8 .

Mehrovta, V. and M.L.Gupta., 1989. Seasonal variation in certain blood constituents in camel. Ind. J. Anim. Sci 51: $1179-1180$.

More, T., A.K. Rai and M. Singh., 1980. Note on certain biochemical responses of sheep and goats exposed to thermal stress. Ind. J. Anim. Sci 50: $10-12$.

Nazifi, S., H.R. Gheisari and H. Poorabbas., 1999. The influence of thermal stress on serum biochemical parameters of dromedary camels and their correlation with thyroid activity. Comp. Haematol. International 9: $49-54$.

Nyang-ao, J.M.N., M.W. Olaho, J.M. Maribei and J.K. Omuse., 1997. A study of serum hematological and biochemical parameters of normal dromedary camel in Kenya. J. Camel pract. Res. 4: $31-33$.

Saleh, M.A. and G.H. El-Sokkary., 2003. Clinical reference values for blood serum proteins in nomadic Bedouin camels (Camelus dromedarius) in Egyptian Oasis. Assiut Vet. Med. J. 49: 160 - 173.

Sarwar, A. and M.A. Majeed., 1997. Interrelationship between 30 parameters of blood in normal one-humped camel in summer. J. Camel pract. Res. 4: 35 - 39. 
SAS. 1999. SAS User's Guide: Statistics version 8 Edition SAS Inst., Inc., Cary, NC. E.J.

Schalm, O.W., N.C. Jain and T. Carroll., 1975. Veterinary hematology., 3rd ed. Philadelphia, Lea and Febiger.

Shaffer, L., J.D. Roussel and K.L. Koonce., 1981. Effects of age, temperature-season and breed on blood characteristics of dairy cattle. J. Dairy Sci. 64: $62-70$.

Sharma, D.P., P.D. Malik and K.L. Sapra., 1973. Age-wise and species-wise haematological studies in farm animals. Ind. J. Anim. Sci. 43: 289 - 295.

Taher, H.H., 1985. Effect of Season of The year and Breed on Some Blood Components, Water Requirements and Metabolism in Sheep and Goats. M.Sc. Thesis, Faculty of Agriculture, Alex. Univ. Egypt.

Ulmasov, H.V., K.K. Karaev, V.M. Lyashko and M.B. Evgem'ev., 1993. Heat-shock response in camel (Camelus dromedarius) blood cells and adaptation to hyperthermia. Comp. Biochem. Physiol. 106: 876 - 872. 
التغيرات الموسمية في بعض المقاييس الهيماتولوجية والبيوكميائية لإنـاث الإبل وحيده

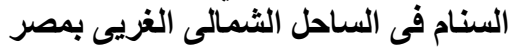

محمد طارق عبد الفتاح بدوى1، حمدى عبد العزيز جاويش، مـروة على خليفة1، فرحات النوتى²، جمال عبد الرحيم حسن بـ2

1- قسم الإنتاج الحيوانس والدواجن، مركز بحوث الصحراء، المطرية، القاهرة|، مصر، 2- قسم الإنتاج

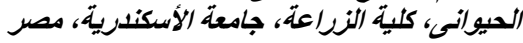

أجريت هذه الدراسة في محطة بحوث مريوط التابعة لمركز بحوث الصحر اء علي 4 من النوق وحيدة الناء

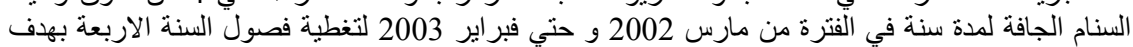

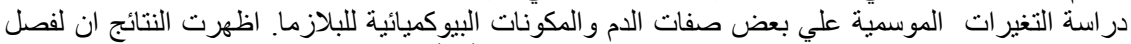

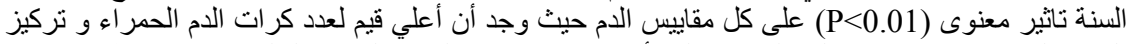

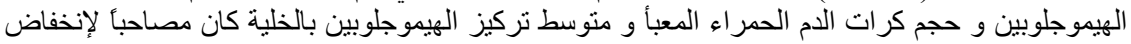

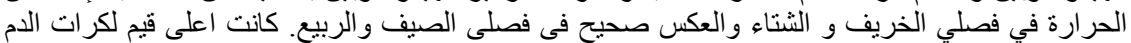

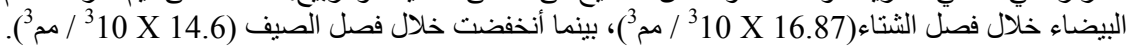

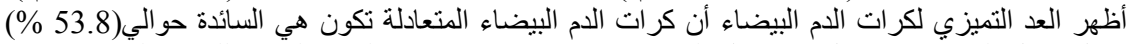

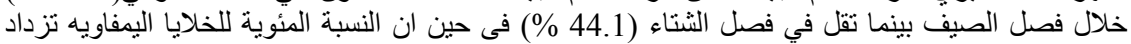

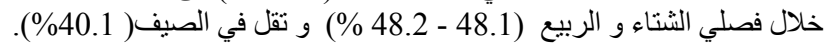

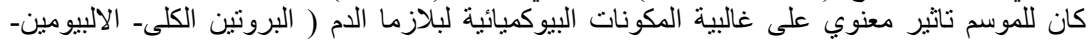

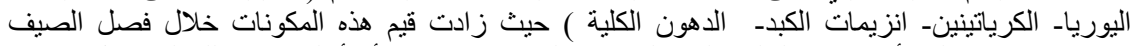

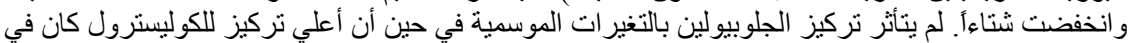

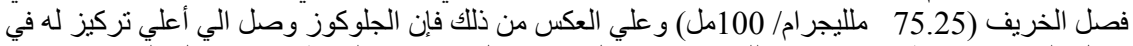

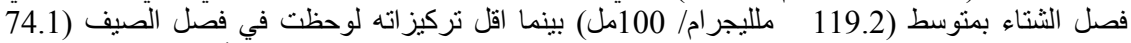

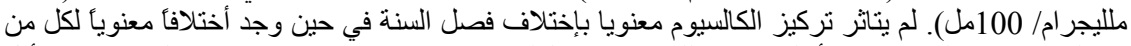

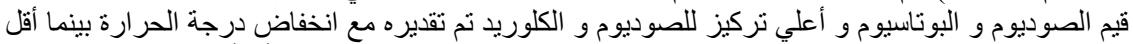

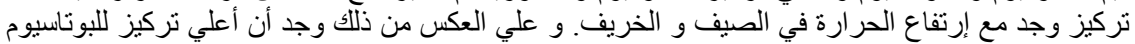

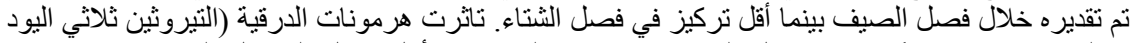

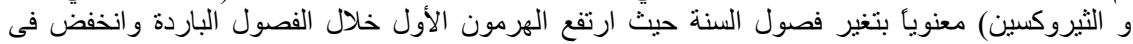

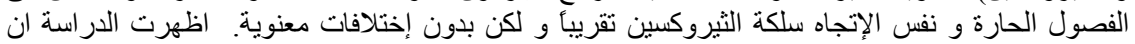

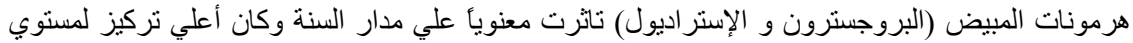

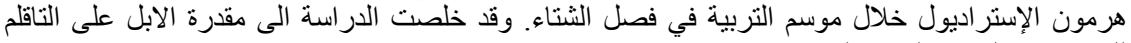

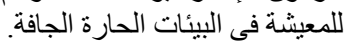

